Hunady, J., Pisar, P., Musa, H., \& Musova, Z. (2017). Innovation support and

economic development at the regional level: panel data evidence from Visegrad

countries. Journal of International Studies, 10(3), 147-160. doi:10.14254/2071-

$8330.2017 / 10-3 / 11$

\title{
Innovation support and economic development at the regional level: panel data evidence from Visegrad countries
}

\author{
Jan Hunady \\ Faculty of Economics, Matej Bel University in Banska Bystrica \\ Slovakia \\ Email:jan.bunady@umb.sk
}

\section{Peter Pisar}

Faculty of Economics, Matej Bel University in Banska Bystrica

Slovakia

Email:peter.pisan@umb.sk

\section{Hussam Musa}

Faculty of Economics, Matej Bel University in Banska Bystrica

Slovakia

Email: hussam.musa@umb.sk

\section{Zdenka Musova}

Faculty of Economics, Matej Bel University in Banska Bystrica

Slovakia

Email: zdenka.musova@umb.sk

Abstract. The paper deals with the problem of innovation support and economic development at the regional level. The innovation potential still differs significantly among the EU regions. Perhaps the key factor determining innovation potential and performance of a region is $\mathrm{R} \& \mathrm{D}$ expenditure. The main aim of the paper is to test the potential relationship between gross domestic expenditure on $\mathrm{R} \& \mathrm{D}$ and economic development of the regions. Our dataset consists of the data on the regions of four Visegrad countries during the period of 2001-2014. We assume the existence of non-linear relationship and expect that $\mathrm{R} \& \mathrm{D}$ expenditures are significantly lower in less developed regions. Using the panel Granger causality and panel regression analysis based on these data, we provide insight into the potential relationship between regional economic development measured in terms of GDP per capita and investments in R\&D controlling for the number of R\&D employees. Our results strongly suggest that higher regional GDP per capita is associated with higher regional gross domestic expenditure on R\&D (GERD) per inhabitant. GERD per capita appears to be exponentially rising with regional GDP per capita. We have also found significant regional disparities in terms of innovation performance.
Received: June, 2017 1st Revision: July, 2017 Accepted: October, 2017 10.14254/2071$8330.2017 / 10-3 / 11$ 
Keywords: innovation support, R\&D expenditure, economic development, European Union, NUTS 2 regions.

JEL Classification: O30, O32, R58

\section{INTRODUCTION}

For more than 50 years, since the neoclassical theory of economic growth by Robert Solow was introduced, researchers and economists all over the world are trying to find answers to the questions around different levels of successful economic growth and prosperity. This has been accompanied by the search for new ways of understanding growth, and out of this emerged a new perspective on economic growth, which put technology and innovation, rather than capital accumulation, at the frontline. Increasingly, the ability of poorer countries or regions to catch up with the richer ones was seen not only - or mainly - as a reflection of their ability to generate (or attract) sufficient investments, but also as a capacity to absorb the existing technologies while generating new ones (that is, to innovate) (Fagerberg, 2010). The innovation support especially by increasing $\mathrm{R} \& \mathrm{D}$ expenditures could be seen as a feasible way to increase economic development in less developed regions. However, less developed regions usually have much lower innovation potential and absorption capacity.

We have focused our attention especially on $\mathrm{R} \& \mathrm{D}$ expenditure at the regional level which could be seen as a key factor affecting innovation performance. Furthermore, R\&D expenditure is often considered as a necessary prerequisite for innovation. Our research aims to test the potential relationship between gross domestic expenditure on R\&D (GERD) and economic development of the regions measured by regional GDP per capita. We assumed that $R \& D$ expenditures are significantly lower in less developed regions which could be in line with the so-called regional innovation paradox. This could be the consequence of lower innovation potential and capacity.

In the next section we review the literature related to this issue and discuss the problem of regional innovation performance. In the third section we introduce the methodology and data used in empirical analysis. The most important results of the analysis are summarized in the fourth section. The paper ends with the final conclusions and remarks.

\section{LITERATURE REVIEW}

Innovations help any entity to achieve higher qualitative and quantitative levels and help to maintain and develop competitiveness. Schumpeter (1987) introduced the concept of innovations in economic theory in his work Theory of Economic Development. He found that innovation is one of the main preconditions for economic growth. Grossman and Helpman (1991) followed Schumpeter's knowledge and explored the relationship between industrial innovation and economic growth at the macro level and dependency rates of innovation on market conditions at the micro level. In their work they confirmed the need to create innovation in relation to long-term economic growth and, moreover, stressed the need for commercialization of new knowledge and its subsequent placement in the market. Several authors agree on the importance of innovation on the economy and give them an important place in the long-term economic growth, and social changes. While older works were focused more on the impact of industrial innovation of products and services at the national level, recent publications include a deeper understanding of the issue of new knowledge on a number of levels. Stiglitz (1997), moreover, emphasizes the theory of knowledge and skills to increase the competitive advantage of the company. Bucek (2006) characterizes innovation as 
an event occurring at a particular location that causes market or organizational breaks. Regions that have high innovation performance achieved higher economic growth, greater international competitiveness and ultimately a superior standard of living of the regions (Acs et al., 2013). There are several approaches to division of innovation, but the authors agree on the categories of innovation, product, process, marketing or market. The creator of innovation is mostly the business sector, but innovation can also be found in the public sector, and through possible mutual cooperation. Depending on the type of wares that gives rise to various types of innovation, the public sector tries to innovate their services while businesses sector mostly provide technological innovation.

Dunning (2002) identifies the innovative processes as the main engine of economic development and defends countries in the global market. The innovation process is the most important part of creation of new knowledge and its subsequent placement in the market, but Fagerberg (2006) shows the wide orientation of economists to generate innovation, while the innovative process is known as a "black box", the functioning of which is not quite clear. Several authors, however, point to the importance of filling the innovation process (Verloop, 2005). De la Mothe and Paquet (2012) attributed the importance of the innovative process and stated that innovation is irrelevant to the economy if it is not part of an interactive mechanism within the environment in which they arise. Eliminating barriers in the innovation is possible through greater concentration of innovation processes. Concentration of innovative processes at the regional level can save on transaction costs, due to the location of innovation actors in one region and simpler security of products, services, labor and information itself as needed by participating actors (Hudec et al., 2009). Lingelbach (2015) identifies the innovation process similar to Sabadka and Lesková (2002) in the context of three main parts - creation of an invention, creation of innovation, and diffusion of the innovation. They all depend on the complexity of the process and the complexity of different cultures. It is similar to Hudec et al. (2009) concept for the need for greater concentration of innovative processes to lower national levels. In the context of innovation, the EU efforts to stimulate innovations create a number of guidelines and strategies at the national and regional level.

The most acclaimed explanation of the term innovation is at present the comprehensive definition in the Oslo manual (Kovacova, 2007), which was published in 1997 by OECD (OECD, 1997): „Technological innovations of products and processes (abr. TPP innovations) which include new products and processes based on new technologies, or significant technical improvements of already existing products and processes. TPP innovation is implemented when the product is launched in the market (product innovation) or a new process innovation is introduced." OECD also defines four basic categories of innovations which create a base for further evaluation of innovation performance of companies and regions. We consider the following categories:

- product innovation,

- process innovation,

- organization innovation,

- marketing innovation.

Innovation policy of the EU is mostly based on the support of the enterprise sphere. This helps to contribute towards better industrial performance and so to support meeting broader social objectives such as industrial growth, increased employment rate and competitiveness of the industry within society and its sustainability. One of the key documents supporting growth of investments into innovations and innovative solutions is Strategy 2020, approved by the Committee in 2010. This strategic document also confirmed the Lisbon Strategic aim to increase the investment ratio of science, research and innovation at least to the level of 3\% GDP of member countries. At present and with the exception of Sweden and Denmark, none of the member countries fulfils the set objective of this investment ratio. 
The innovative performance of regions increased when firms are encouraged to innovate by interacting with support organizations and with firms within their region. The institutional characteristics, knowledge infrastructures as well as knowledge transfer systems of the region are all crucial stimuli for promoting innovation activities in the region (Doloreux and Parto, 2005). Among investments into research and development and innovation performance, there seems to be an explicit correlation (see for example Raymond, St-Pierre, 2010) of higher shares of expenditures into research and development and the increase of innovation performance of a region. Thus, increasing regional expenditures on research and development is a key tool supporting innovation activities in the region. The spatial distribution of $R \& D$ expenditures among the regions have been examined so far in the EU countries (Martin et al., 2005) as well as in other countries such as for example in China (Zhong et al., 2011; Wei and Wu, 2008).

Despite the greater need of less developed regions to spend more on innovation, their lower absorption capacities represent a significant restriction for further R\&D expenditures. This situation is often referred to as the regional innovation paradox (Oughton et al., 2002). Hence, we could assume that less developed regions invest significantly less into $\mathrm{R} \& \mathrm{D}$ despite the fact that economic development would increase innovation capacity and could open the door for even higher R\&D expenditure.

Based on this theoretical characteristic we could assume that there could be a positive but non-linear relationship between GDP per capita and R\&D expenditures in the region. Only very few studies has been dealt with this issue based on the empirical data so far. Lederman and Maloney (2003) based on the panel data analysis found that R\&D expenditures rise exponentially with the development level of the country measured by GDP per capita. We took into certain extent similar approach, but apply it on regions rather than countries. As far as we know, this is one of the first studies which examine this problem based on panel regional data from Visegrad countries. Our analysis aims to primary test this theoretical assumption based on the secondary panel data for Visegrad countries. These countries have been chosen according to geographical economic and cultural proximity which could ensure relatively good homogeneity at regional level.

\section{METHODOLOGY}

In this section we describe applied methodology and data in detail. The main focus of this paper is to test the potential relationship between expenditure on research and development and economic development of the region in Visegrad countries (Czech Republic, Hungary, Poland and Slovakia). We also want to reveal the actual state and development of regional disparities in $\mathrm{R} \& \mathrm{D}$ expenditures in these four countries.

Firstly, we compared total regional gross domestic expenditure on R\&D (GERD) in years 2001 and 2014 and extracted GERD for the enterprise business sector only. Secondly, we analysed the development of GERD from 2001 to 2014 using the time series for the best performing and the worst performing regions in each of the four countries.

Secondary data used in the analyses have been retrieved from EUROSTAT (2016) database. Our dataset consists of the data for the regions of four Visegrad countries during the period 2001-2014. Thus, we get together 455 individual observations. All variables used in the analysis are described in Table 1. 
Description of variables used in the analysis

\begin{tabular}{|c|c|c|}
\hline Variable & Description & Source \\
\hline $\begin{array}{l}\text { GERD per capita } \\
- \text { total }\end{array}$ & $\begin{array}{l}\text { Total intramural R\&D expenditure (GERD) by NUTS } 2 \text { regions (Euro } \\
\text { per inhabitant) }\end{array}$ & \multirow{4}{*}{$\begin{array}{l}\text { Eurostat database } \\
\text { [rd_e_gerdreg] }\end{array}$} \\
\hline $\begin{array}{l}\text { GERD per capita - } \\
\text { enterprise sector }\end{array}$ & $\begin{array}{l}\text { R\&D expenditure (GERD) by sectors of performance and NUTS } 2 \\
\text { regions (Euro per inhabitant) - business enterprise sector }\end{array}$ & \\
\hline $\begin{array}{l}\text { GERD per capita } \\
\text { - government }\end{array}$ & $\begin{array}{l}\text { R\&D expenditure (GERD) by sectors of performance and NUTS } 2 \\
\text { regions (Euro per inhabitant) - government sector }\end{array}$ & \\
\hline $\begin{array}{l}\text { GERD per capita - } \\
\text { higher education }\end{array}$ & $\begin{array}{l}\text { R\&D expenditure (GERD) by sectors of performance and NUTS } 2 \\
\text { regions (Euro per inhabitant) - higher education institutions }\end{array}$ & \\
\hline GDP per capita & $\begin{array}{l}\text { Regional gross domestic product (GDP) by NUTS } 2 \text { regions. Purchasing } \\
\text { power standard (PPS) per inhabitant. }\end{array}$ & $\begin{array}{l}\text { Eurostat database } \\
\text { [nama_r_e2gdp] }\end{array}$ \\
\hline $\begin{array}{l}\text { R\&D } \\
\text { PERSONNEL }\end{array}$ & $\begin{array}{l}\text { Total R\&D personnel and researchers by NUTS } 2 \text { regions. Full-time } \\
\text { equivalent (FTE). }\end{array}$ & $\begin{array}{l}\text { Eurostat database } \\
\text { [rd_p_persreg)] }\end{array}$ \\
\hline
\end{tabular}

Soure: Authors.

In the next stage, we examined the potential relationship between total R\&D expenditures and GDP per capita for each region using the panel Granger causality tests and the panel fixed-effects and random effects models. These methods were widely used in many previous studies. Granger causality test is appropriate especially in the cases when the direction of potential effect is not known. However, this effect estimated by panel Granger causality test could still not be referred as direct causal relationship. This method is therefore also suitable in our case. Hence, we used this in order to test the direction of potential effect between GDP per capita R\&D expenditures. In the next phase we need to select between fixed effects and random effects models to choose the most appropriate one. The choice between these models was based on the results of the Hausman test, which is the usual procedure in this situation. However, we still used several different models in our analysis in order to check for robustness.

All variables used in the models were also tested for weak stationarity using the panel stationarity test. Based on the results of these tests (shown in the Appendix) we can conclude that all selected variables are found to be non-stationary at levels but appear to be stationary at the first differences. Hence, in our regression models we decided to take the first differences of the variables.

\section{EMPIRICAL RESULTS AND DISCUSSION}

First of all we examine the gross domestic expenditure on R\&D (GERD) in NUTS 2 regions of each Visegrad country. The data for NUTS 2 regions in Czech Republic are graphically illustrated in Figure 1. We can see that Prague region is the one with the highest GERD per inhabitant from all four countries. The Prague region has more than twice as much GERD per capita than the second region in Czech Republic. However, the GERD in "Jihovýchod" (southeast region) experienced very strong growth during the examined period from 2001 to 2014 and it is actually the third best performing region from the whole Visegrad group. The share of business enterprise sector on total GERD is highest in "Strední Čechy" (middle) and "Severovýchod" (northeast) regions and "Severozápad" (northwest) .

The situation is to some extent similar in Hungary (see Figure 2), where we can see that the highest GERD per capita is located in "Közép-Magyarország" the region around the capital city Budapest. However, the differences between other regions appear to be less significant compared with the Czech 
Republic. The growth of GERD over the selected period is in most other regions somewhat smaller than in Czech Republic.

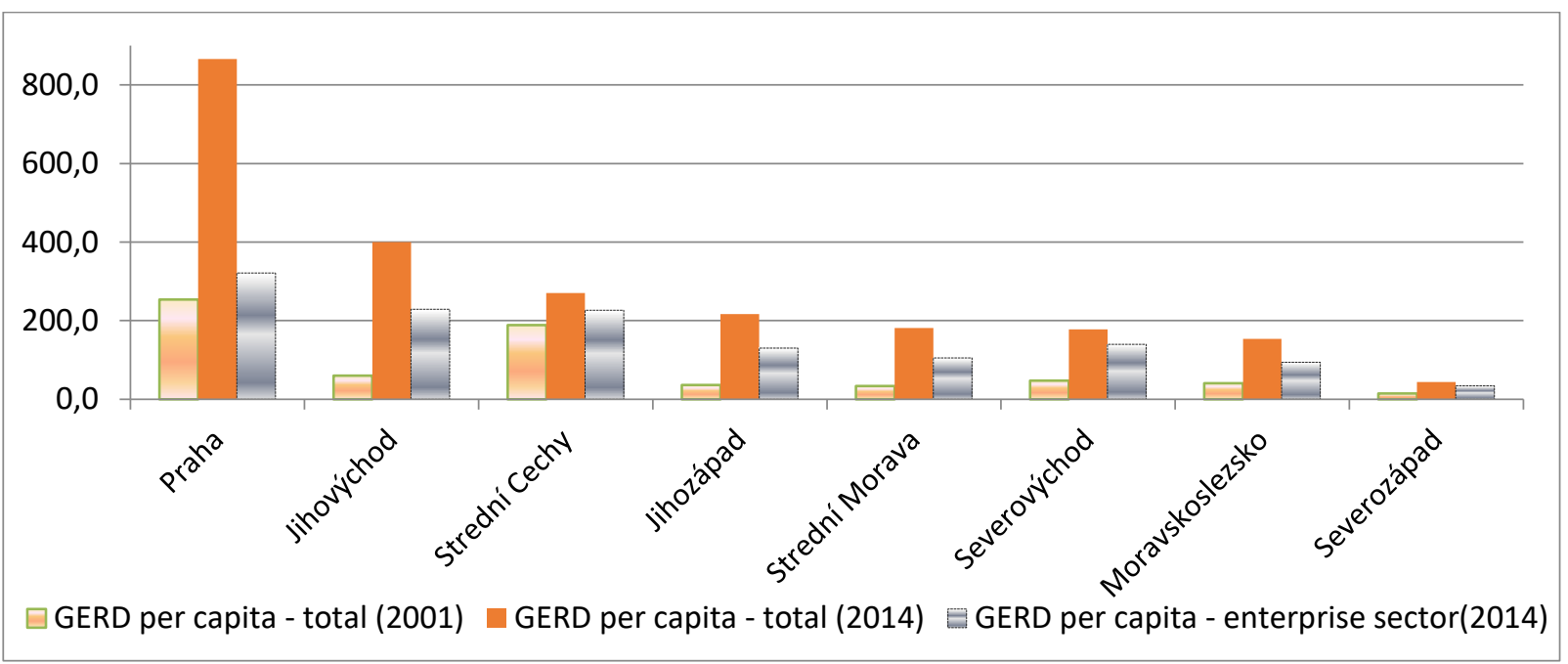

Figure 1. Regional gross domestic expenditure on R\&D per inhabitant in the Czech Republic (by NUTS 2 regions)

Source: Authors based on the data from Eurostat database.

Note: The names of the regions are stated in Czech. Their English translations are as follows (in order as listed in the graph - form left to right): Prague, Southeast, middle Czech, southwest, Northeast, Silesia, Northwest.

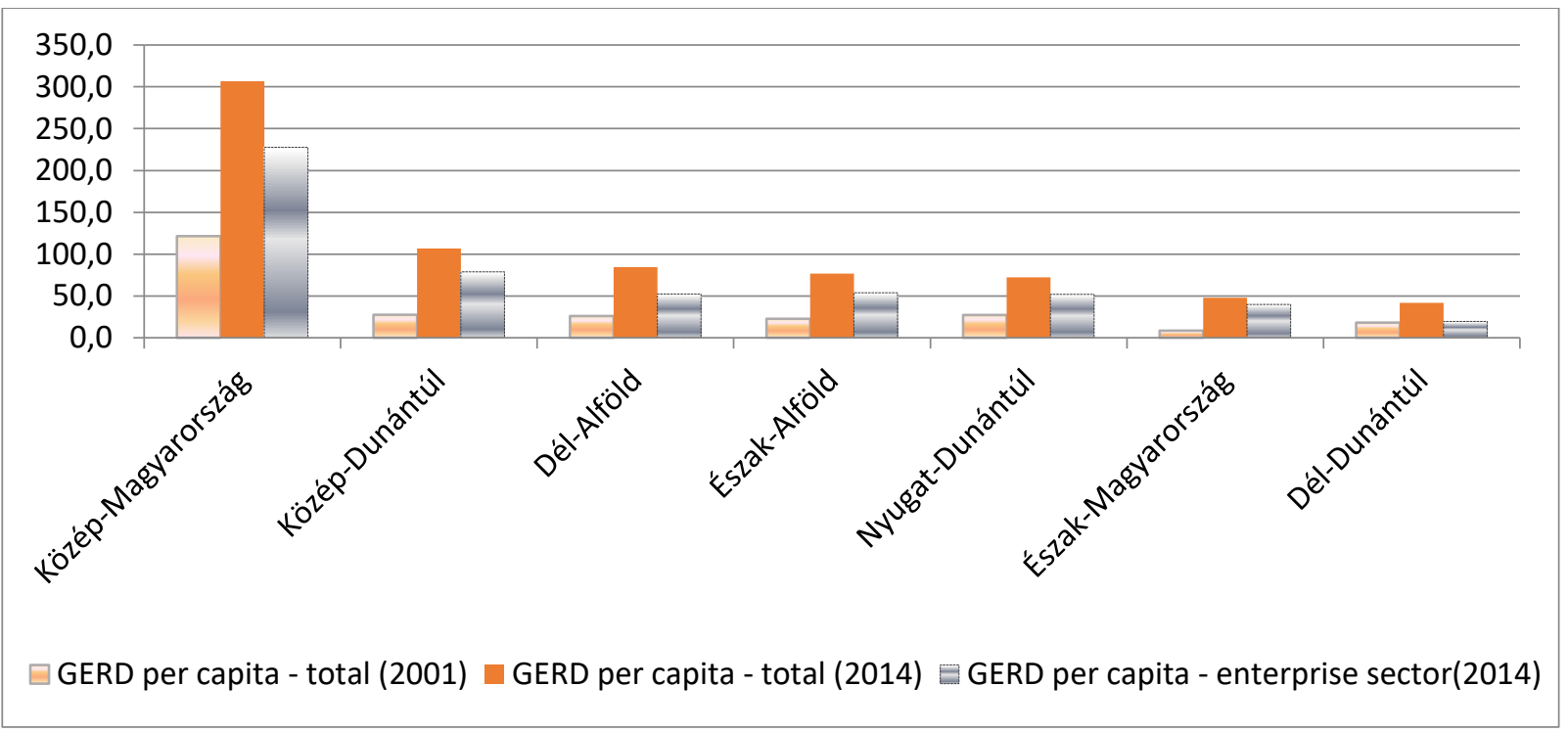

Figure 2. Gross domestic expenditure on R\&D per inhabitant in Hungary (by NUTS 2 regions) Source: Authors based on the data from Eurostat database.

Note: The names of the regions are stated in Hungarian. Their English translations are as follows (in order as listed in the graph - form left to right): central Hungary,central Transdanubia, southern Great Plains, northern Great Plains, western Hungary, northern Hungary, southwest Hungary. 
The distribution of GERD per capita over the NUTS 2 regions in Poland and Slovakia is shown in Figure 3 and Figure 4. In both countries the best performing regions are those with the capital cities (the region "Mazowieckie" in Poland and the region "Bratislavský kraj" in Slovakia). Despite this fact, the difference between the best performing region and other regions is much higher in Slovakia. While the Bratislava region is by far the best performer in Slovakia and the second best performing region in the Visegrad group, other regions in Slovakia are significantly less successful.

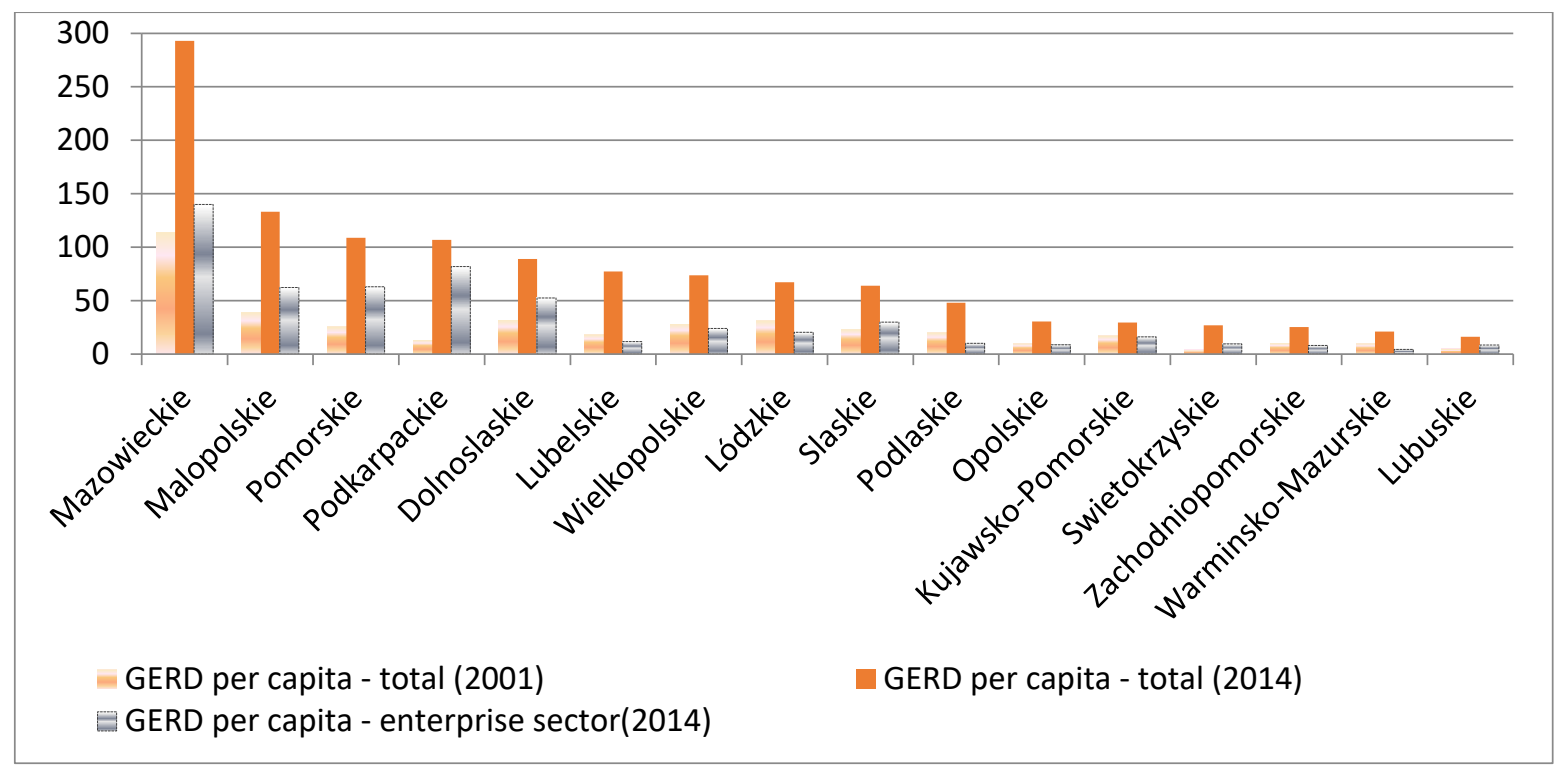

Figure 3. Gross domestic expenditure on R\&D per inhabitant in Poland (by NUTS 2 regions) Source: Authors based on the data from Eurostat database.

Note: The names of the regions are stated in Polish.

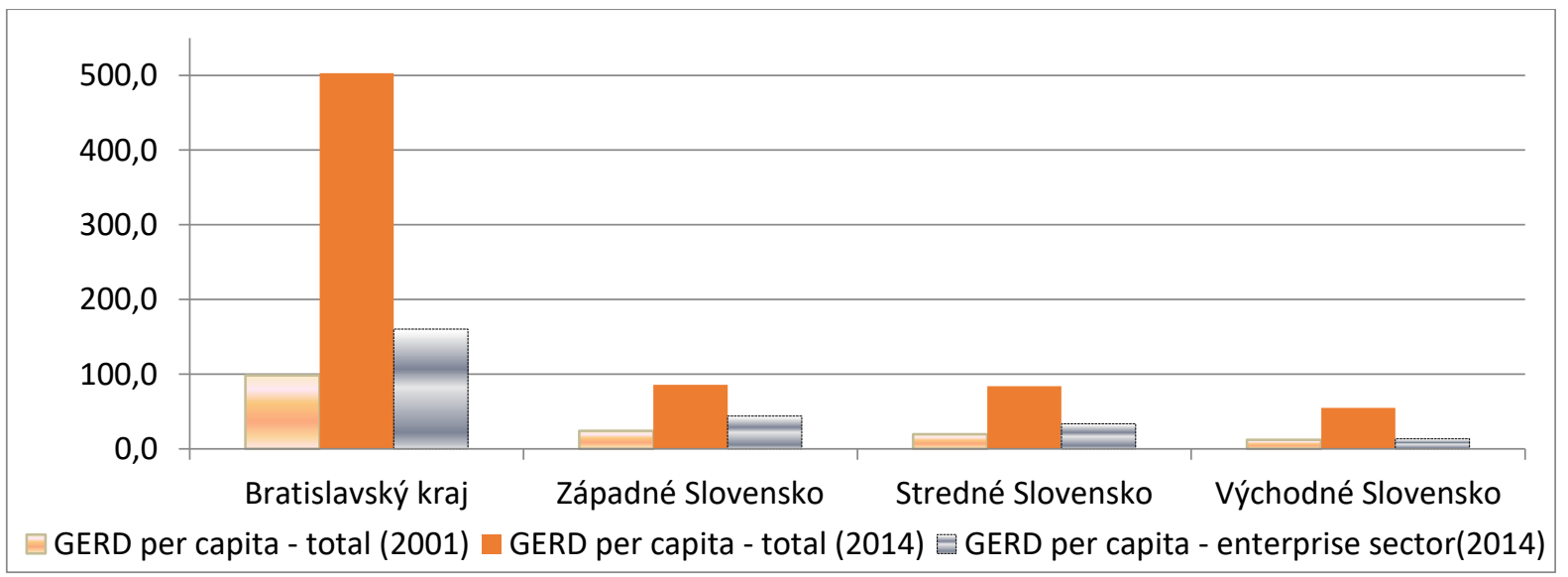

Figure 4. Gross domestic expenditure on R\&D per inhabitant in Slovakia (by NUTS 2 regions) Source: Authors based on the data from Eurostat database.

Note: The names of the regions are stated in Slovak. Their English translations are as follows (in order as listed in the graph - form left to right): Bratislava region, western Slovakia, middle Slovakia, eastern Slovakia. 
When we look more in detail to individual components of R\&D expenditure in Slovak regions, we can see that the success of the Bratislava region is especially built on R\&D expenditure from the government and the business sector (see Figure 5). A higher proportion of business sector R\&D expenditure is also evident in „Západné Slovensko“ (western Slovakia). On the other hand, a relatively high share of higher education R\&D expenditure is found in the region „Stredné Slovensko“ (middle Slovakia).

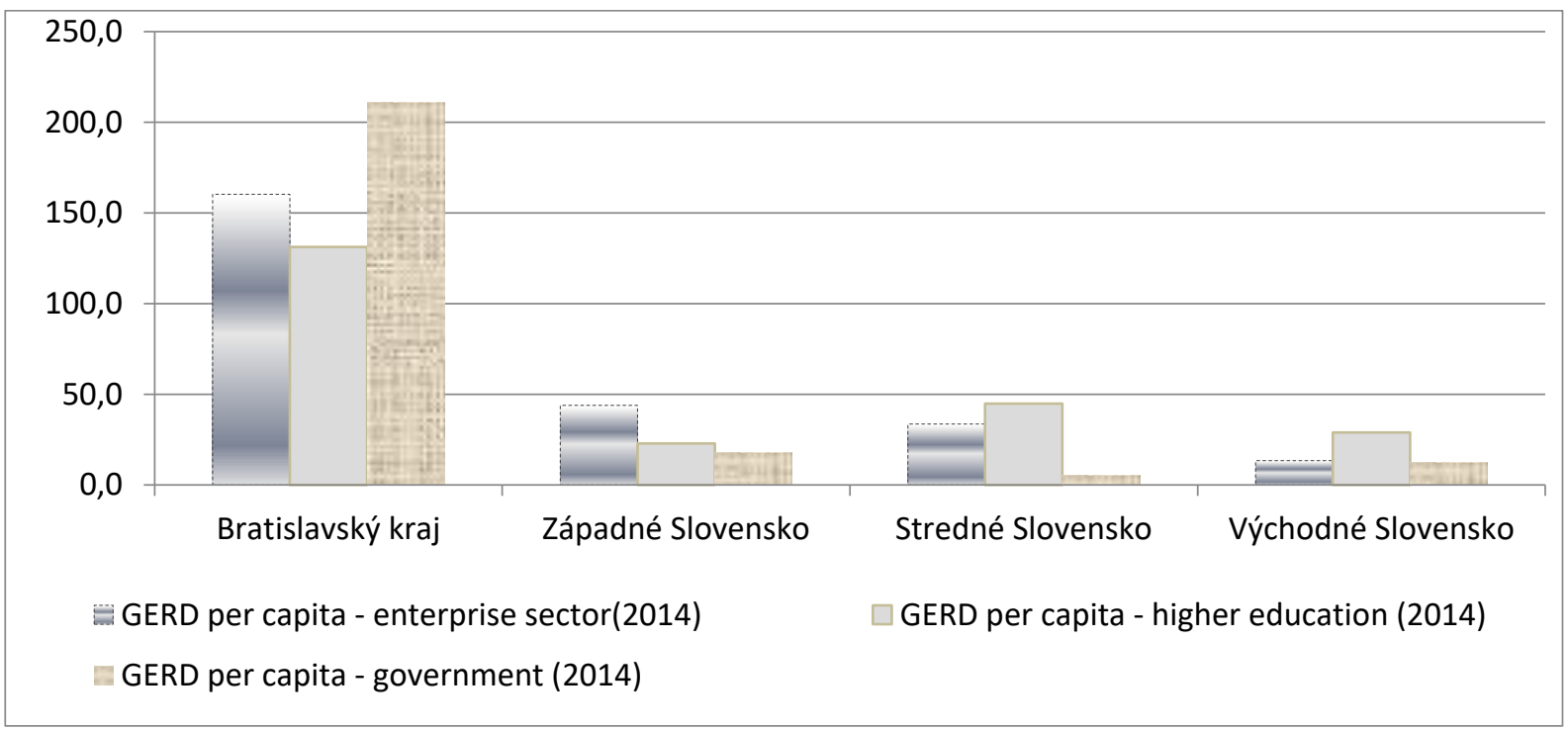

Figure 5. GERD per capita by different sectors in Slovakia (by NUTS 2 regions)

Source: Authors based on the data from Eurostat database.

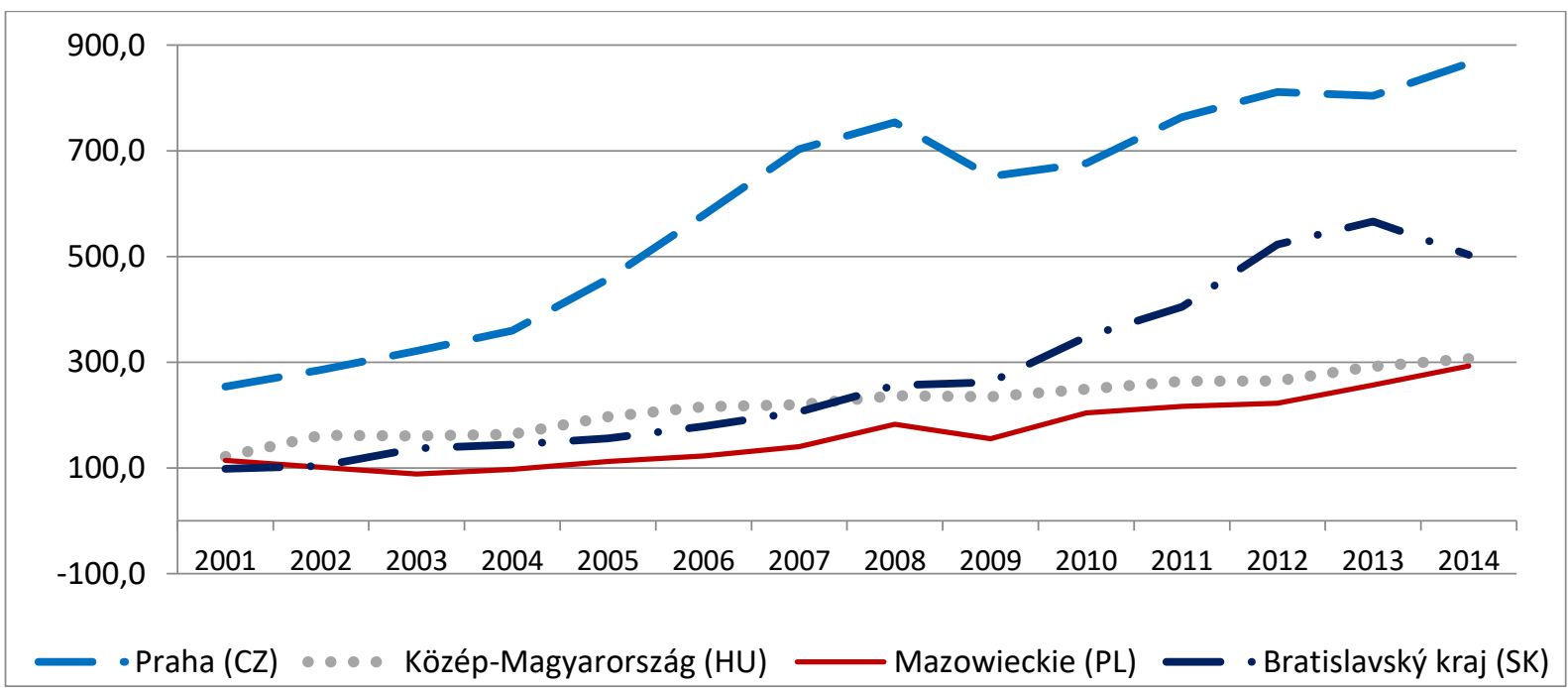

Figure 6. The development of GERD per capita in top performing regions for each country. Source: Authors based on the data from Eurostat database.

Figure 6 show the development of regional GERD per capita during the selected period in the best performing regions (being the capital region). On the one hand, it is evident that the most rapid increase 
was captured in Prague and Bratislava regions. On the other hand, GERD per capita in top performing regions from Hungary and Poland increased only slightly during the period.

GERD per capita in the worst performing regions also had an increasing trend by 2012 as it can be seen in Figure 7. Despite, certain decrease in more recent period, the current level is still relatively higher compared with previous years.

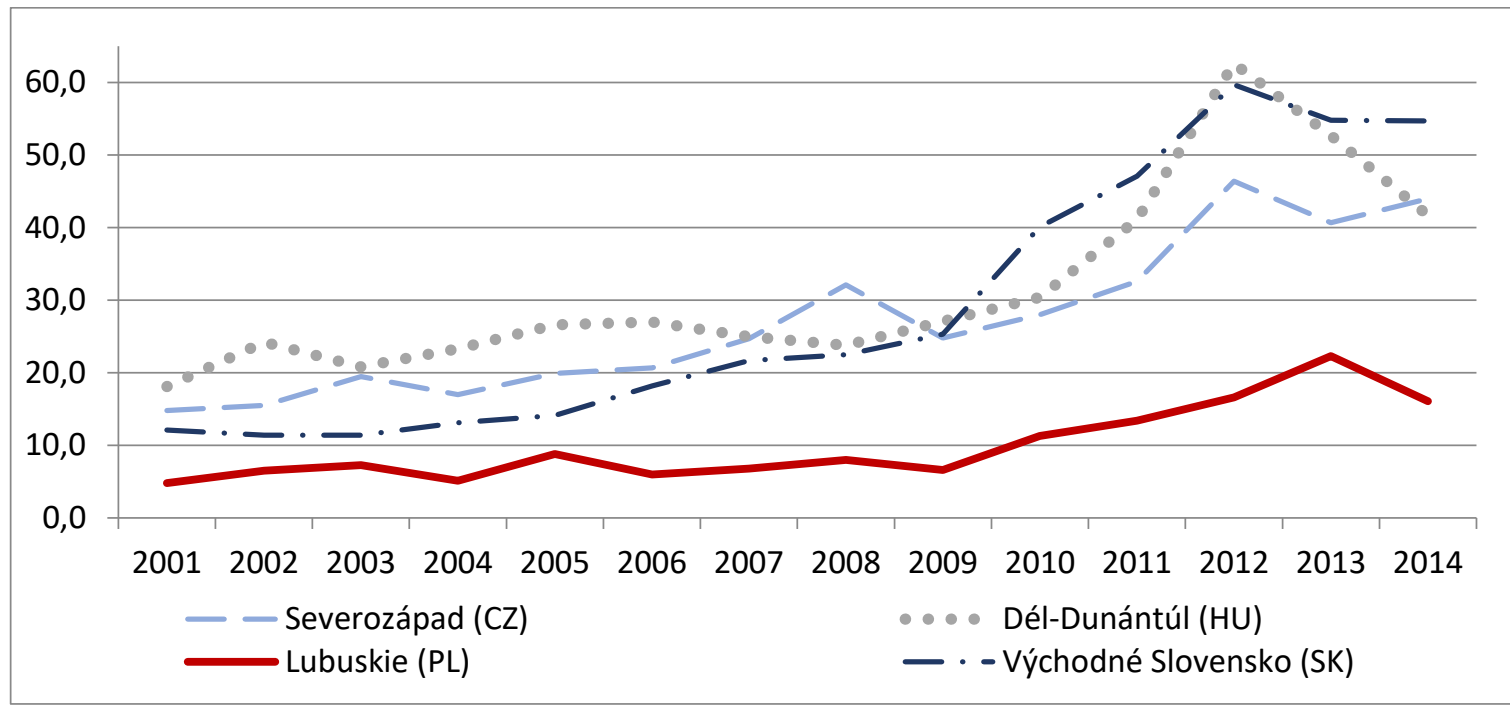

Figure 7 The development of GERD per capita in the worst performing regions for each country Source: Authors based on the data from Eurostat database.

In line with our main aim we also want to examine the potential relationship between regional GDP per capita and regional GERD per capita. Figure 8 graphically demonstrate this kind of relationship using polled data that take into account data for each year and each region as individual observations.

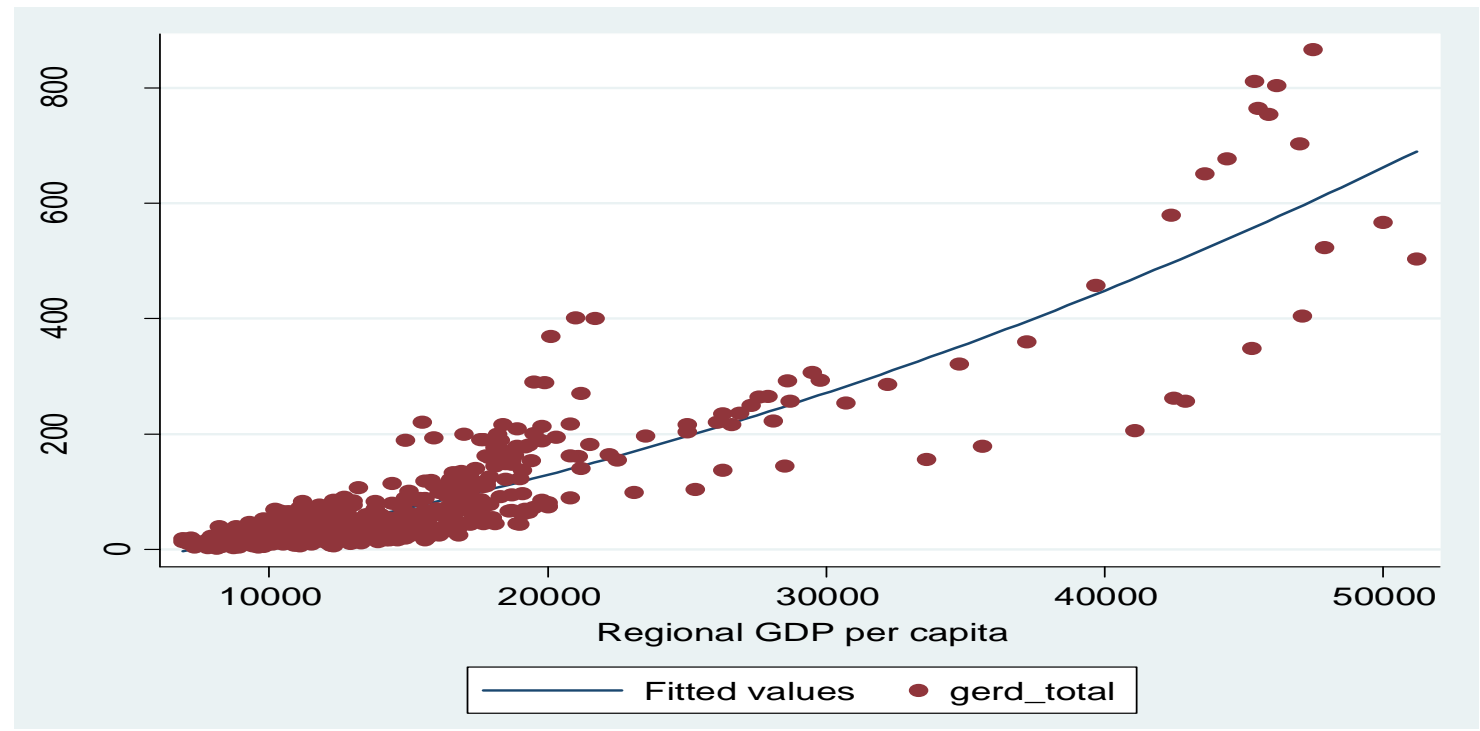

Figure 8. Potential relationships between GERD per capita and GDP per capita (all regions) Source: Authors based on the data from Eurostat database. 
GERD per capita increased with increasing GDP per capita in the region. The relationship appears to be in the form of slight exponential growth. Similar relationship is also shown in Figure 9, where we decided to abstract from the most developed regions and looked in more detail at those with lower GDP per capita. The potential relationship is very similar to the previous graph, but the exponential growth is even more evident here.

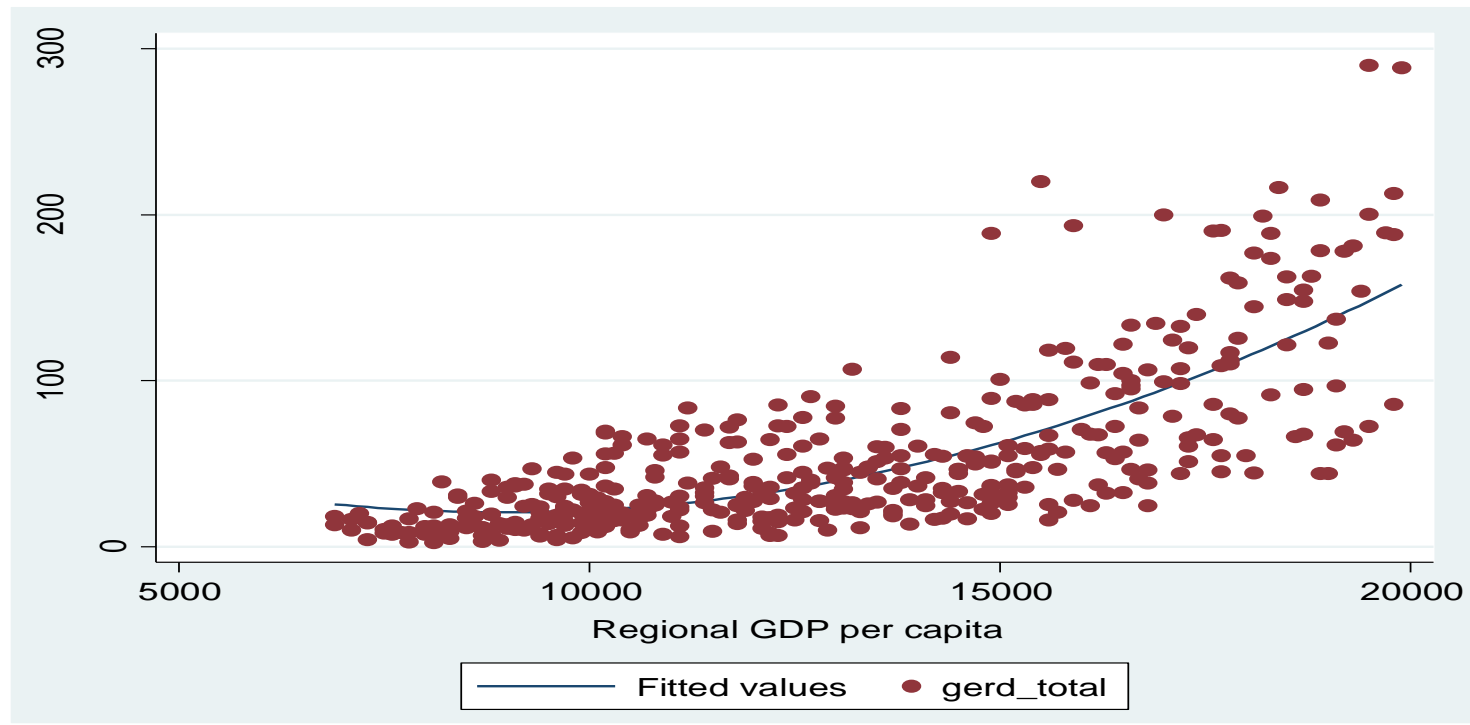

Figure 9. Potential relationship between GERD per capita and GDP per capita for regions with less developed regions (under 20000 PPS per inhabitants)

Source: Authors based on the data from Eurostat database.

The basic descriptive statistic of two main independent variables used in further models is provided in Table 2.

Basic descriptive statistic for two main independent variables

\begin{tabular}{|l|c|c|}
\hline & GERD per capita - total & R\&D PERSONNEL \\
\hline Mean & 84.84959 & 4914.366 \\
\hline Median & 43.70000 & 2940.000 \\
\hline Maximum & 865.7000 & 32547.00 \\
\hline Minimum & 2.200000 & 190.0000 \\
\hline Std. Dev. & 122.1699 & 5666.262 \\
\hline Skewness & 3.558639 & 2.457237 \\
\hline Kurtosis & 18.23460 & 8.959637 \\
\hline Observations & 490 & 490 \\
\hline
\end{tabular}

Source: Authors.

We further tested the assumed relationship based on the panel Granger causality test between both variables (in the first difference forms) as shown in Table 3. The results indicate that there is the causality in the Granger sense from GDP per capita to GERD per capita, which means that economic development 
of the region could in the short run, Granger cause gross total expenditures on R\&D per inhabitant in the region to rise. The short-run causality in the opposite direction was not statistically significant in any test.

Table 3

Results of panel pairwise Granger causality tests

\begin{tabular}{|l|c|c|c|}
\hline & F-statistic & F-statistic & F-statistic \\
\hline Number of lags: & 1 lag & 2 lags & 3 lags \\
\hline $\begin{array}{l}\Delta \text { GDP per capita does not Granger Cause } \\
\Delta \text { GERD per capita }\end{array}$ & $18.36^{* * *}$ & $9.88^{* * *}$ & $6.01^{* * *}$ \\
\hline $\begin{array}{l}\Delta \text { GERD per capita does not Granger Cause } \\
\text { GDP per capita }\end{array}$ & 0.11 & 0.22 & 0.93 \\
\hline $\begin{array}{l}\Delta \text { R\&D PERSONNEL does not Granger Cause } \\
\Delta \text { GERD per capita }\end{array}$ & $25.66^{* * *}$ & $23.23^{* * *}$ & $14.53^{* * *}$ \\
\hline $\begin{array}{l}\Delta \text { GERD per capita does not Granger Cause } \\
\Delta \text { R\&D PERSONNEL }\end{array}$ & 0.15 & 0.43 & 1.03 \\
\hline \begin{tabular}{l} 
Number of observations \\
\hline
\end{tabular}
\end{tabular}

Source: Own calculation based on the data from Eurostat database.

Note: symbols $* / * *$ denotes significance at $1 \%$ / $5 \%$ level.

After testing the Granger causality, we further used panel regression techniques in order to verify the significance as well as intensity of assumed relationship. The results of all models are summarized in Table 4. Panel data have been used in all mentioned models. In line with the results of the stationarity test we used all variables in their differenced forms. We applied the fixed-effect as well as random effects panel regression. However, fixed-effects regression appears to be a more appropriate solution based on the results of the Hausman test. Thus, we used cross-section fixed effects, period fixed-effects as well as both type of fixed-effects in separate regressions. R\&D personnel have been used in all models as control variable, with potential effect on the GERD per capita in the region. The regression 1.1 contains only differenced GDP per capita and of R\&D personal stuff as independent variables. The cross section random effects model has been applied in this case. On the other hand cross-section fixed effects models have been used in regression models 1.2 and 1.3. In regression 1.3 we also applied GDP per capita in quadratic form. All three variables used in these models have been statistically significant at 1\% level. The same is true for regressions 1.4 and 1.5. However, we applied period fixed effects in regression 1.4 and cross-section and period fixed effects in regression 1.5 .

Thus we can say that our results suggest the existence of statistically significant effect of GDP per capita on GERD per capita. Based on the graphical outputs shown in Figure 8 and Figure 9, we also decided to include quadratic term into regressions. Both variables appear to be statistically significant at the $1 \%$ level and the results support our assumption about the existence of non-linear exponential relationship between GDP per capita and GERD per capita. As expected, our results also indicate that the number of total R\&D personal is another variable potentially affecting the GERD per capita. 
Results of panel regression models

\begin{tabular}{|c|c|c|c|c|c|}
\hline \multicolumn{6}{|c|}{ Dependent variable: $\Delta$ GERD per capita } \\
\hline & 1.1 & 1.2 & 1.3 & 1.4 & 1.5 \\
\hline$\Delta$ GDP per capita & $\begin{array}{c}0.008^{* * * *} \\
(0.176)\end{array}$ & $\begin{array}{c}0.006^{* *} \\
(2.57)\end{array}$ & $\begin{array}{c}-0.007 * * * \\
(-3.57)\end{array}$ & $\begin{array}{c}-0.012^{* * *} \\
(-5.43)\end{array}$ & $\begin{array}{c}-0.010^{* * * *} \\
(4.58)\end{array}$ \\
\hline$\Delta($ GDP per capita 2$)$ & & & $\begin{array}{c}2.63 \times 10-7 * * * \\
(3.46)\end{array}$ & $\begin{array}{c}2.63 \times 10-7 * * * \\
(7.12)\end{array}$ & $\begin{array}{c}2.94 \times 10-7 \text { *** } \\
(3.30)\end{array}$ \\
\hline $\begin{array}{l}\Delta \text { R\&D } \\
\text { PERSONNEL }\end{array}$ & $\begin{array}{c}0.013^{* * *} \\
(9.74)\end{array}$ & $\begin{array}{c}0.010^{* * *} \\
(4.36)\end{array}$ & $\begin{array}{c}0.009 * * * \\
(4.46)\end{array}$ & $\begin{array}{c}0.010^{* * *} \\
(10.09)\end{array}$ & $\begin{array}{c}0.008^{* * *} \\
(4.70)\end{array}$ \\
\hline $\begin{array}{l}\text { Fixed effects (FE) / } \\
\text { Random effects (RE) }\end{array}$ & $\begin{array}{c}\text { Cross-section } \\
\text { RE }\end{array}$ & $\begin{array}{c}\text { Cross- } \\
\text { section FE }\end{array}$ & $\begin{array}{c}\text { Cross-section } \\
\text { FE }\end{array}$ & Period FE & $\begin{array}{l}\text { Cross-section \& } \\
\text { period FE }\end{array}$ \\
\hline Hausman test statistics & $31.26 * * *$ & & & & \\
\hline $\mathrm{R} 2$ & 0.28 & 0.37 & 0.42 & 0.43 & 0.48 \\
\hline Adjusted R2 & 0.28 & 0.32 & 0.37 & 0.42 & 0.41 \\
\hline Akaike criterion & & 8.475 & 8.40 & 8.28 & 8.36 \\
\hline F-statistic & $88.81^{* * *}$ & $7.003^{* * *}$ & $8.296^{* * *}$ & $22.45^{* * *}$ & $7.53^{* * *}$ \\
\hline $\begin{array}{l}\text { Number of } \\
\text { observations }\end{array}$ & $\begin{array}{c}455 \\
(13 \times 35) \\
\end{array}$ & $\begin{array}{c}455 \\
(13 \times 35) \\
\end{array}$ & $\begin{array}{c}455 \\
(13 \times 35)\end{array}$ & $\begin{array}{c}455 \\
(13 \times 35) \\
\end{array}$ & $\begin{array}{c}455 \\
(13 \times 35)\end{array}$ \\
\hline
\end{tabular}

Source: Own calculation based on he data from Eurostat database.

Note: symbols (.) denotes $z$-statistics and $* / * *$ denotes statistically significant at the $1 / 5$ percent level. Standard errors have been corrected for heteroscedasticity.

According to the results there seem to be an exponential growth of GERD per capita with rising GDP per capita. Perhaps, this could be referred as a causal effect of GDP per capita, but we have to mention that, despite the results of Granger causality potential problem of endogeneity could not be completely ruled out, thus it should be more appropriate to further explain the results more as correlation rather than direct causality. Thus, growth of regional gross expenditure on $\mathrm{R} \& \mathrm{D}$ pre inhabitant appears to be positively associated with growth of regional GDP per capita, while the growth of expenditures in R\&D. The same is true for number of $R \& D$ personnel. Our results are in line with the theoretical assumption about the regional innovation paradox mentioned for example by Oughton et al. (2002). Moreover, the results on regional level are similar to those obtained at the country level by Lederman and Maloney (2003).

\section{CONCLUSION}

Innovation is often seen as driving force of regional development. Hence, one of the primary aims of less developed regions should be to improve their innovation performance, which could be done by increasing $\mathrm{R} \& \mathrm{D}$ expenditures in the region. However, the increase in effective allocation of $\mathrm{R} \& \mathrm{D}$ expenditure is limited by innovation capacity of the region. Our research was focused on regions of Visegrad countries and we have found significant regional disparities in gross domestic expenditures on R\&D. The Prague and Bratislava regions are specifically the leading ones and there are many regions that are significantly lagging behind them in $\mathrm{R} \& \mathrm{D}$ expenditure. The level of $\mathrm{R} \& \mathrm{D}$ expenditure is increasing in almost every region in our sample over the selected period 2001-2014. Hence, there is very little evidence for significant divergence or convergence trend between less-developed and the best developed regions. Business enterprise sector participated in the total R\&D expenditure in most all regions. 
Our results also found positive correlation between regional gross domestic R\&D expenditures (GERD) per capita and regional GDP per capita. The results of panel Granger causality and panel regression analysis suggest potential positive effect of GDP per capita on GERD. This relationship appears to be nonlinear, while GERD per capita seems to be an exponential function of GDP per capita. Less developed regions have significantly lower innovation capacity and therefore they invest in innovation much less than well-developed regions, despite the need to invest even more. In seems likely that more investment in human resources and research infrastructure could represent a possible way out of this problem. For the long run growth, it is also necessary to maintain balance in all components of $R \& D$. Thus, $R \& D$ expenditure in the business enterprise sector, higher education sector, government sector as well as non-profit sector should all be maintained in sufficient amount.

Despite our best effort to ensure appropriate methodology, there is still some potential drawback regarding to the data and methodology. Despite testing for reverse causality, the endogeneity problem could not be completely ruled out. The potential problem lies in the omitted-variable bias, because, the selection of control variables was strongly limited by the availability of observations for the entire panel.

\section{ACKNOWLEDGEMENT}

This work has been supported by the Scientific Grant Agency of Slovak Republic under project VEGA No. 1/1009/16 „Innovation potential of the regions of Slovakia, its measurement and innovation policy at the regional level“".

\section{REFERENCES}

Acs, Z. J., Groot, G.L.F., \& Nijkamp, P. (2013). The Emergence of the Knowledge Economy, a Regional Perspective. Berlin: Springer-Verlag. doi 10.1007/978-3-540-24823-1.

Bucek, M. (2006). Regionálny rožvoj. Bratislava: Vydavatel'stvo EKONÓM.

De la Mothe, J., \& Paquet, G. (2012). Local and Regional System of Innovation. (Vol. 14). Springer Science \& Business Media.

Doloreux, D., \& Parto, S. (2005). Regional innovation systems: Current discourse and unresolved issues. Technology in society, 27(2), 133-153. doi:10.1016/j.techsoc.2005.01.002

Dunning, J. H. (2002). Regions, Globalization and the Knowledge Economy. London: Oxford University Press. doi:10.1093/0199250014.001.0001.

Eurostat. (2016). Retrieved 12 December, 2016 from: http://epp.eurostat.ec.europa.eu.

Fagerberg, J. (2010). The changing global economic landscape: the factors that matter. In Robert M. Solow \& JeanPhilippe Touffut (Ed.). The Shape of the Division of Labour: Nations, Industries and Households. Edward Elgar., 6-31. doi: $10.4337 / 9781849809122$

Fagerberg, J. (2006). Innovation: A Guide to the Literature. In: Fagerberg, J., Mowery, D., Nelson, R.R. 2006. The Oxford Handbook of Innovation. Nortfolk: Oxford University Press, 2004. doi:10.1093/oxfordhb/9780199286805.001 .0001

Grossman, G.M., \& Helpman, E. (1991). Innovation and growth in the global economy. London: The MIT Press.

Hudec, O. a kol. (2009). Podoby regionálneho a miestneho roøvoja. Košice: Ekonomická fakulta TU.

Kovacová, L. (2007). Úloha inovačných centier v znalostnej ekonomike. Transfer inováciú, 10, 22-25.

Lederman, D. \& Maloney, W.F. (2003). Research and development (R\&D) and development. Policy, Research working paper no. WPS 3024. Washington, DC: World Bank. Retrieved from http://documents.worldbank.org/curated/en/778751468739477640/Research-and-development-R-D-anddevelopment.

Lingelbach, D., Sriram, V., Mersha, T., \& Saffu, K. (2015). The Innovation Process in emerging economies. Enterpreneurship and Innovation, 16(1), 5-17. doi:10.5367/ijei.2015.0172. 
Martin, C., Mulas-Granados, C., \& Sanz, I. (2005). Spatial distribution of R\&D expenditure and patent applications across EU regions and its impact on economic cohesion/Distribución espacial de los gastos en $\mathrm{I}+\mathrm{D}$ y de patentes en las regiones europeas y su impacto en la cohesión económica. Investigaciones regionales, (G), 41.

Oughton, C., Landabaso, M., \& Morgan, K. (2002). The regional innovation paradox: innovation policy and industrial policy. The Journal of Technology Transfer, 27(1), 97-110. doi:10.1023/A:1013104805703.

Raymond, L., \& St-Pierre, J. (2010). R\&D as a determinant of innovation in manufacturing SMEs: An attempt at empirical clarification. Technovation, 30(1), 48-56. doi:10.1016/j/technovation.2009.05.005.

Sabadka, D., \& Lesková, A. (2002). Inovačný proces a riadenie inovácií v podniku. Transfer inováciú, 5(1), 49-51.

Schumpeter, J.A. (1987). Teória hospodárskeho vývoja. Bratislava: Pravda.

Stiglitz, E. (1997). Ekonomie verejného sektora. Praha: GRADA Publishing.

Verloop, J. (2005). Insight in innovation. Amsterdam: Elsevier, B.V.

Wei, S. H., \& Wu, G. S. (2008). An empirical study on spatial distribution and its changing trends of regional R\&D expenditure in China. R\&D Management, 13(1).

Zhong, W., Yuan, W., Li, S. X., \& Huang, Z. (2011). The performance evaluation of regional R\&D investments in China: An application of DEA based on the first official China economic census data. Omega, 39(4), 447-455.

\section{APPENDIX}

Appendix 1

Results of panel unit root tests. Source: Own calculation

\begin{tabular}{|l|c|c|c|c|}
\hline & Levin, Lin \& Chu & $\begin{array}{c}\text { Im, Pesaran and } \\
\text { Shin } \\
\text { W-stat }\end{array}$ & $\begin{array}{c}\text { ADF - Fisher Chi- } \\
\text { square }\end{array}$ & $\begin{array}{c}\text { PP - Fisher Chi- } \\
\text { square }\end{array}$ \\
\hline GERD per capita & 4.85 & 9.13 & 10.35 & 15.05 \\
\hline$\Delta$ GERD per capita & $-17.63^{* * *}$ & $-13.76^{* * *}$ & $292.60^{* * *}$ & $365.01^{* * *}$ \\
\hline GDP per capita & 0.16 & 5.54 & 22.52 & 32.42 \\
\hline$\Delta$ GDP per capita & $-18.22^{* * *}$ & $-12.50^{* * *}$ & $273.02^{* * *}$ & 57.37 \\
\hline R\&D PERSONNEL & 1.27 & 4.16 & 51.78 & $359.88^{* * *}$ \\
\hline$\Delta$ R\&D PERSONNEL & $-20.08^{* * *}$ & $-14.34^{* * *}$ & $292.87^{* * *}$ & \\
\hline
\end{tabular}

